\title{
A LOJALITÁS KLASZTEREI A PARTNERI ÉS A FOGYASZTÓI PIACOKON
}

Az utóbbi évtizedben számos nemzetközi tanulmány figyelmeztetett arra, hogy a jó minôség és a fogyasztói elégedettség nem elég a cégek profitjának növeléséhez, hanem sokkal inkább a lojalitást, a húséget kell a középpontba állítani. Mi is a húség és hogyan mérhetố a lojalitás? Van-e egy általánosítható modell, vagy különböző tényezók játszanak szerepet a lakossági fogyasztók, illetve az üzleti partnerek ragaszkodásában? Mely szférákban van jelentôsége a lojalitás mérésének, és van-e értelme a húség vizsgálatának olyan szervezeteknél, amelyek egyelőre kvázi monopolhelyzetben vannak? A dolgozat ezekre a kérdésekre keresi a választ, amikor az elméleti háttér bemutatása mellett egy magyarországi energiaszolgáltató lakossági fogyasztóinak lojalitását kutató empirikus vizsgálat eredményeit mutatja be, és szemelvényeket közöl egy B2B piacon végzett lojalitáskutatás eredményeiról is. A kutatások egyrészt felhívják a figyelmet arra, hogy a lojalitást más dimenziók határozzák meg a szervezeti és a fogyasztói piacokon, másrészt azt is jelzik, hogy mindkét piacon nagyon különbözó attitúddel rendelkezó partnerek, illetve fogyasztók találhatók, azaz a lojalitás megközelítése, annak kezelése differenciált marketingstratégiákat követel.

Kulcsszavak: elégedettség, energiapiac, B2B-lojalitás, lakossági lojalitás kvázi monopolpiacon, lojalitás mérése

Miközben egyre inkább teret nyer az a feltételezés, hogy a fogyasztói és partneri lojalitás a jövedelmezóség záloga, számot kell vetnünk azzal a ténnyel, hogy sem a lojalitás definiálása, sem az arra ható tényező́k meghatározása nem nyert elfogadottságot a marketingelméletben, és az empirikus kutatások következtetései sem meggyőzőek. A tanulmány két empirikus kutatás eredményeinek bemutatásával kívánja feltárni a fentiekben vázolt különbségeket. Az energiaszolgáltatók fogyasztói piacán ezerfôs reprezentatív mintán végzett kérdőíves vizsgálat adatainak elemzésével a tanulmány egyrészt rámutat arra, hogy mely tényezók befolyásolják a magyarországi lakossági energiafogyasztók lojalitását, másrészt igyekszik felvázolni a különbözó fogyasztói attitúddel rendelkező csoportok legfontosabb jellemzóit. A szervezeti piacon végzett kérdőíves és fókuszcsoportos vizsgálat a lojalitást befolyásoló tényezók specialitásait vázolja fel a B2B-piacon, valamint bemutatja a partneri elkötelezettség klasztereinek jellemzőit. A klaszterek elemzése segítségül szolgálhat a piacok szegmentálására, és árnyaltabb, hatékonyabb piaci stratégiák kidolgozására.

\section{A lojalitás elméleti háttere}

Ahhoz, hogy egy szervezet megórizze piacát, meg tudja tartani fogyasztóit, partnereit, mindenekelőtt a fogyasztók és a partnerek lojalitását kell felépíteni. Elsőként Deming fogalmazta meg, hogy a jövőben „nem lesz elegendő, ha olyan fogyasztókkal rendelkezünk, akik pusztán csak elégedettek" (Deming, 1986: 141. p.). Mások is felhívták a figyelmet a vevőmegtartás jövedelmezőségére, arra, hogy a lojális vevôkör kialakítása lényegesen kevesebb ráfordítással jár, mint az akvizíció (Fornell - Wernerfelt, 1987). Pénzügyi adatok is alátámasztják, hogy érdemes a lojalitást kialakítani. Egy 14 vállalatnál végzett vizsgálat bizonyította, hogy 5\%-os vevő́megtartás 25-95\%-os nettó jelenérték növekedést eredményezett a profitban (Reicheld - Sasser, 1990).

A lojalitás szerepe a B2B kapcsolatokban is megjelent, de a marketing-szakirodalomban sem a lojalitás definiálása, sem az azt befolyásoló tényezốk azonosítása kérdésében nem született egyetértés a szakemberek körében. A szerzók egy része alig lát különbséget a szervezeti piacokon megnyilvánuló partneri húség 
meghatározásában, mások azonban hangsúlyozzák a B2B-lojalitás sajátosságait. Ugyanezekkel a problémákkal találkozhatunk a fogyasztói lojalitás definiálása és a lojalitást befolyásoló tényezốk specifikálása kapcsán is. A felmerült kérdésekre adandó válaszokat tovább bonyolítják az egymásnak ellentmondó kutatási eredmények, amelyek sem cáfolni, sem megerősíteni nem tudják az elméleti dilemmákat. Az utóbbi néhány évben olyan egymásnak ellentmondó kutatási eredmények születtek, amelyek számos új irányt jelölnek ki a jövốbeni marketingkutatások számára (Zeithaml, 2000).

\section{A lojalitás definiálási kísérletei}

Bár a lojalitás fogalmával kapcsolatban megoszlanak a vélemények, abban többnyire egyetértenek a szerzók, hogy a lojalitás egyfajta elkötelezettséget, húséget jelent, de az elkötelezettséget a különbözó dimenziókban (szervezeti-fogyasztói) más megközelítésben tárgyalja a szakirodalom. A lojalitás definiálásának szakirodalma a B2C relációkban sokkal gazdagabb, mint a B2B kapcsolatoknál, aminek legfóbb oka abban keresendő, hogy a szervezeti piacokon maga az elnevezés is sokszínúbb, és a megközelítések is árnyaltabbak. A következókben a kétfajta megközelítés elméleti hátterének rövid áttekintését adjuk.

\section{A fogyasztói lojalitás definiálása}

$\mathrm{Ki}$ tekinthetố lojális fogyasztónak? Hüséges fogyasztónak tekinthető́k azok, akik szeretik a termékeinket és szolgáltatásainkat, gyakran vásárolják azokat, úgy érzik, hogy a termék/szolgáltatás megéri az árát, jobb, mint a versenytársaké, jellemzói találkoznak az elvárásokkal, vágyakkal, és a fogyasztók másoknak is ajánlják a terméket/szolgáltatást. Hogyan definiálható a lojalitás? A fogyasztói lojalitás meghatározását bonyolítja, hogy annak nagyon sok aspektusa lehet. A szakirodalomban széles körú elemzéseket találhatunk a márkahúségre, a „bolthúségre”, a vevơhúségre és az ismételt vásárlásokra vonatkozóan (Kandampully, 1998). A lojalitást Tellis úgy definiálja, mint az újravásárlási hajlandóságot, illetve az azonos vagy hasonló márkavásárlás relatív arányait (Tellis, 1988), Newman és Werbel szerint pedig húséges az a fogyasztó, aki úgy vásárol újra egy márkát, hogy csak azt az egyet veszi figyelembe, és nem végez más márkákhoz kapcsolódó információkeresést (Newman - Werbel, 1973). R. L. Oliver szerint e definíciók hiányossága, hogy csak azzal foglalkoznak, mit tesz a fogyasztó, miközben a lojalitás hátterében ennél fontosabb folyamatok húzódnak meg. Oliver a lojalitás eltérô szintjeit különbözteti meg. A kognitív (megismerô) lojalitás szintjén az elérhetô információk alapján a vevő az egyik márkát preferálja a többivel szemben. E fázis alapja önmagában a márkába vetett hit, amely korábbi vagy jelenlegi tapasztalatok alapján alakul ki, és a lojalitás ekkor még csak a márka felé irányul. Az affektív (befolyásoló) lojalitás az ismételt vásárlások következtében jön létre, és egyfajta márkalojalitást jelent, a konatív („akaratív”) lojalitás pedig erôs elkötelezettséget jelent a márkaspecifikus újravásárlásra. Ez a fajta lojalitás már motiváló, és hasonlóan a többi jó benyomáshoz, az igény elốre jelezhetô, de nem feltétlenül realizált. Az action (tevékeny) lojalitás szintjén a fogyasztó a vásárlást akadályozó tényezókön is túljut. Oliver szerint a végsố fokozat az, amikor a fogyasztó „bármilyen körülmények között, és bármilyen áron" fenntartja újravásárlási szándékát, és ezért áldozatokat is képes hozni. Az igazi lojalitás egy mélyebben gyökerező elkötelezettség az újravásárlásra, a másoknak való ajánlásra a jövőben és folyamatosan, ami ismétlődô vásárlást eredményez az esetenkénti negatív hatások és a váltásra ösztönzó marketing-erófeszítések ellenére is (Oliver, 1999: 36. p.). Az elpártolók (switchers) és a maradók (stayers) közötti eltéró jellemzóket vizsgálva hasonló megállapításokra jutottak Jaishankar és társai, akik megkülönböztetnek aktív, illetve passzív lojalitást (Jaishankar et al., 2000). Olyan nézetekkel is találkozhatunk, amelyek szerint el kell felejteni az elégedett és lojális fogyasztót. Ken Blanchard és társa szerint egy szervezet fogyasztói csak azért elégedettek, mert alacsonyak az elvárásaik, és mert nincs más, aki jobbat kínálna nekik. Véleményük szerint a jövớben nem lesz elég pusztán elégedett és lojális fogyasztókkal rendelkezni, ha igazi üzleti sikert akarunk, ki kell alakítani a „rajongóan lelkes” fogyasztói bázist (Blanchard - Bowles, 1993).

Az újabb kutatások arra hívják fel a figyelmet, hogy a lojalitás és elkötelezettség sem szinonim fogalmak. Pritzhard és szerzôtársai (Pritzhard et al., 1999) a fogyasztói lojalitás és elkötelezettség közötti különbségeket hangsúlyozzák, és a márkahúség esetében próbálják elemezni a kapcsolatot a két tényezó között. A szerzők szerint a lojális attitúd lojális magatartáshoz vezet, és a lojalitást a márka-újravásárlásokkal mérik. Az elkötelezettség azonban, megítélésük szerint, ennél sokkal több: erős vágy a folyamatos kapcsolatra, a fogyasztók azonosulása a szervezeti célokkal és értékekkel.

A fogyasztói elégedettség és lojalitás profitra gyakorolt hatásának érdekes összefüggéseire mutat rá az a svéd kutatás, melynek eredményei szerint a tárgyiasult termékeknél a lojalitás negatív hatással is lehet a jövedelmezôségre, míg a szolgáltatásoknál ez a hatás pozitív. A tárgyiasult termékek és szolgáltatások iránti lojalitást vizsgálva Edvardsson és társai felhívják a 
figyelmet arra, hogy különbség van „kiérdemelt” és „vásárolt” lojalitás között. A „kiérdemelt” lojalitást a jó minőséggel, a kedvező fogyasztói értékeléssel lehet elérni, amikor a fogyasztó azért tér vissza a termékhez/ szolgáltatáshoz, mert azzal elégedett, a „vásárolt” lojalitás azonban valamilyen kedvezmény (kupon, árcsökkentés) felkínálásán alapul, amely rövid távú újravásárlást eredményez csak (Edvardsson et al., 2000).

Hofmeister-Tóth és társai a lojalitás és a vevômegtartás árnyaltabb értelmezésére figyelmeztetnek: szerintük a fogyasztói húség, a lojalitás statikus, míg a vevômegtartás dinamikus fogalom, és a vevômegtartás alapjai visszanyúlnak a tranzakciós költségelmélethez, valamint a szociálpszichológia területéhez (Hofmeister - Tóth et al., 2003).

A lojalitás dinamikus megközelítésének, azaz a lojalitás kialakulási folyamatának fázisait elemezve Costabile a fogyasztói lojalitást úgy definiálja, mint a fogyasztó és a szervezet közötti legerôsebb kapcsolatot. Ez a megközelítés nem egyszerúen azt az ,igazi lojalitást" jelenti, amelyet Jacoby és Chestnut hipotetizálnak (Jacoby - Chestnut, 1978), hanem a fogyasztó és a szervezet közötti olyan kapcsolatot, amely a kölcsönösséggel megerősített, a méltányosság és a korrektség által fenntartott, és így az együttmúködési attitúdöt és magatartást is magában foglalja (Costabile, 2000). Garbarino - Johnson (1999) az elégedettség, a bizalom és az elkötelezettség különböző szerepére hívják fel a figyelmet a fogyasztói kapcsolatokban. Megállapításaik szerint a három tényezó hatása más intenzitással jelentkezik az alacsony kapcsolati szintú csoportoknál, mint a magasabb kapcsolati kötődéssel rendelkezóknél. Míg az egyszerú tranzakciós kapcsolatoknál az elégedettség szerepe jelentôsebb, addig szorosabb kötôdés esetén elótérbe kerül a bizalom és az elkötelezettség kérdése a jövő́beli szándékokat illetôen.

Elismerve, hogy a lojalitás pozitív hatással van a profitra, egyes szerzók arra hívták fel a figyelmet, hogy a húséges fogyasztói bázisból célszerú csak a legjövedelmezóbb vásárlói csoportokra koncentrálni az erôket, és e kulcsfogyasztókkal törekedni kell a szoros, hoszszú távú kapcsolatok kialakítására (Reicheld, 1996; Keenan, 2000).

Fentieken túl nem szabad elfeledkezni arról sem, hogy a legújabb kutatások sokkal inkább az elégedetlen fogyasztók motivációira irányulnak, és a vevőmegtartást nem úgy kezelik, mint a lojális fogyasztók attitúdjeinek megismerését, hanem úgy, mint az elégedetlen vevớk elpártolásának megakadályozását (Cary 1999,; Colgate --Norris, 2001; White - Yanamandram, 2004). Számos kutatási eredmény szól arról, hogy ahogy az elégedett fogyasztó nem feltétlenül marad húséges (Jo- nes - Sasser, 1995; Reicheld - Sasser, 1990; Reicheld, 1996; Oliver, 1999; Neal, 1999; Rowley - Dawes, 2000), úgy az elégedetlen fogyasztó sem válik szükségképpen hútlenné (Day, 1984). Vollmer és társai az elégedetlenség ellenére is lojális vásárlók motivációit kutatva arra a következtetésre jutottak, hogy az ilyen vásárlók magatartásában a pszichológiai tényezóknek jelentős szerepe van. Hirschman munkájára (Hirschman, 1970) alapozott modelljükben hangsúlyozzák, hogy az elégedetlen húséges vásárlók bizalma elmélyültebb a cég iránt, ennek következtében hajlamosak a hibák okainak keresésére és a megbocsátásra, valamint megfontoltabban mérlegelik a váltás költségeit. Hipotéziseik tesztelése az empirikus kutatásokban igazolódott (Vollmer et al., 2000).

Esetenként ellentmondás lehet a termékkel/szolgáltatással kapcsolatos attitúd és a vásárlói magatartás között. Lehetnek olyan „szituációs tényezők”, amelyek a negatív attitúd ellenére is vásárlásra késztetik a fogyasztót. Ilyenek például a monopolhelyzet (természetes monopólium), a hiány az adott földrajzi területen (lokális monopólium), társadalmi, pszichológiai jellemzók (csoportok hatása a fogyasztóra, gondolkodásmód stb.).

A fogyasztói lojalitás definiálási kísérleteiról megállapíthatjuk, hogy a hüség értelmezésének sokféle megközelítése nem könnyíti meg a szervezetek dolgát, amikor a vevőmegtartás eszköztárának kidolgozásán munkálkodnak. Éppen ezért minden szervezet számára fontos saját fogyasztóinak kutatása, a különbözô attitúddel bíró fogyasztói csoportok elemzése, és a megtartásukhoz, lojalitásuk kialakításához szükséges hatékony eszköztár kidolgozása (Moloney, 2006).

\section{A lojalitás értelmezése a B2B-kapcsolatokban}

A partneri húség meghatározása a szervezeti kapcsolatokban még árnyaltabb, mint a B2C-relációban, ennek következtében magára a partneri lojalitásra vonatkozóan kevesebb azonosítási kísérlettel találkozhatunk. A hứség megközelítése a „kapcsolatiságon” keresztül történik, és az üzleti szférában sokkal nagyobb a jelentősége az olyan fogalmaknak, mint az elkötelezettség, a bizalom, az együttmúködés, a függőség, az egyenértékúség.

A „klasszikusnak” tekinthetô fogyasztói lojalitásmérési modellek nem tulajdonítanak nagy szerepet a kapcsolatoknak a húséges vevôi bázis megtartásában (Grönholdt et al., 2000; Parasuraman - Grewal, 2000), de a kapcsolati marketing képviselői szerint ez a húség alapja, és a kapcsolatoknak különös szerepe van a B2B lojalitásban. A kapcsolati marketing lényegét hangsúlyozó kutatások valójában a B2B-pi- 
acok elemzésével kezdődtek (Hakansson - Osteberg, 1975; Ford, 1980; Morgan - Hunt, 1994), de a hosszú távú kapcsolatok determinánsainak meghatározására erốs hatással voltak a pszichológia (Thibaut - Kelley, 1959), a gazdaságszociológia (Granovetter, 1985) és a társadalmi hálózatok elméletei (Burt - Minor, 1982; Burt, 1992) is.

A stabil, hosszú távú kapcsolatok jellemzóit egyes kutatások a következókben foglalják össze: elkötelezettség, interakciók, függoóség, kölcsönösség, együttmúködés. Az elkötelezettség úgy is definiálható, mint „tartós vágy egy fontos kapcsolat fenntartására”, és ez a lojalitás előzményének is tekinthetô (Costabile, 2000). Az együttmúködés, a kooperáció is releváns a hosszú távú kapcsolatokban, hiszen kölcsönösséget feltételez. Kutatások bizonyítják, hogy az együttmúködési attitúd függ a tranzakciók folyamán szerzett tapasztalatok alapján kialakult elégedettség szintjétól (Anderson Narus, 1984, 1990), más szerző́k a méltányosságot és egyenértékúséget tekintik az együttmúködés alapjának (Huppertz et al., 1978; Swan - Mercer, 1981; Ganesan, 1994). Az egyenértékúség az outputok és inputok mérlegelésén alapul ugyanabban a cserefolyamatban, és észlelése pozitív hatással lehet az elégedettségi szintre, ha az input-output közötti arány kedvezố és elfogadható a fogyasztó és a partner számára. Az alacsony észlelt egyenértékúség a partneri opportunizmus érzését generálhatja a kevésbé elégedett vásárlóban, de egy adott cserében a korlátozott egyenértékúség nem vált ki elégedetlenséget, ha a kölcsönösség és méltányosság érzése fennmarad. A rövid távú áldozatokat kompenzálja az egyenértékúség érzete hosszú távon (Ganesan, 1994).

Gruen (1995) a kapcsolati elkötelezettséget és az elégedettséget a cserefolyamatban észlelt egyenértékúségből származtatva megállapítja, hogy az egyenértékúség észlelésének magas szintje és a kapcsolatban való konszolidált elkötelezettség szignifikánsan csökkenti az opportunizmus kockázatát. Ford (1980) alapján Dwyer, Schurr-Oh (1987) a kapcsolatiság ötlépcsôs modelljét feltételezik: (1) tájékozottság, tudatosság (2) felderítés (3) expanzió, kiterjesztés (4) elkötelezettség (5) feloldás.

A B2B-szférában a partnerváltás is bonyolultabb, mint a fogyasztói piacon, az esetek többségében a magasabb ráfordítások mellett sokkal nagyobb a váltás kockázata. Az elhagyások költségeinek direkt hatását a lojalitásra és az újravásárlási szándékra számtalan empirikus kutatás igazolta mind a fogyasztói (Aydin - Ozer, 2005; Caruana, 2004; Lee - Cunningham, 2001; Patterson - Smith, 2003), mind az üzleti piacon (Lam et al., 2004; Nielson, 1996; Wathne et al., 2001).
Yanamandram - White (2006) a váltási kockázatot elemezve rámutatnak, hogy az észlelt kockázat sokkal komplikáltabb az üzleti piacokon, mint a fogyasztói piacon, mert a következmények nemcsak a vásárlónál, hanem a szervezet szintjén is jelentkeznek. A személyes kockázat megjelenik a vásárló aggodalmában, és felelősségében, hogy a döntés elégedetlenséghez vezethet (Newall, 1977), a szervezeti kockázat pedig annak mértékétól függ, hogy milyen kockázatot képes elviselni a vállalat (ez méret és pénzügyi helyzet függvénye.)

A lojalitásban, a szervezetek közötti elkötelezettségben, húségben jelentôs szerepe van a személyes kapcsolatoknak is. Empirikus kutatások igazolják, hogy a pozitív megítélésú kapcsolattartó új szervezethez történó távozásával a partner is elhagyja a beszállítót, és a kapcsolattartó új cégétól vásárol (Lindgreen, 2000; Reynolds - Beatty, 1999). Andersen - Kumar (2006) kutatásai arra hívják fel a figyelmet, hogy a pozitív személyes kapcsolat hiánya gátolja a kapcsolat fejlesztését, sốt gyakran a fenntartását is.

A húség megközelítésében gyakori a konfliktusok hatásának vizsgálata a kapcsolatok szorosságára. Az elvárt és a nyújtott teljesítmény közötti különbség konfliktusokat okozhat, de a konfliktusok megfelelő kezelése erősítheti a kapcsolatot, és hüséghez vezethet (Tuckman, 1965).

A kötődés kialakulásához szükség van a bizalomra, melynek elsố lépcsôje az észlelt tényezókön alapuló megelőlegezett bizalom (Singh - Sirdeshmukh, 2000; Vollmer et al., 2000). Az emberi kapcsolat a szolgáltatói folyamat alatt általában erósíti a bizalmat és így a kapcsolatot is, és amikor a vásárlók a bizalomban nem csalódnak, akkor vágynak egy hosszú távú kapcsolat kialakítására és fenntartására, ami elvezet a lojalitáshoz (Evans - Crosby, 1988;, Vollmer et al., 2000). Dwyer - Schurr-Oh (1987) a bizalmat a diszkrét piaci tranzakciókból a folyamatos kapcsolatokba való átmenet kritikus faktoraként kezelik. Costabile (2000) dinamikus modelljében is meghatározó szerepe van a bizalmi tényezőnek.

A fenti megközelítések jelzik, hogy a lojalitás meghatározása semmivel sem egyszerúbb a B2B-relációkban, mint a fogyasztói piacon, ellenkezóleg, a kapcsolatok mögötti nagyobb felelôsség, a váltás ráfordításai és kockázata még bonyolultabbá teszik a partneri lojalitás definiálását.

\section{Empirikus kutatások}

A továbbiakban két empirikus kutatás részeredményeit mutatjuk be azzal a céllal, hogy felfedjük a B2B- és a B2C-piacokon tapasztalható lojalitásdimenziók kü- 
lönbségeit, és rávilágítsunk arra, hogy mindamellett, hogy különbségek tapasztalhatók a lojalitást befolyásoló tényezókben a két piacon, a partnerek és fogyasztók húsége is rendkívül differenciált, a lojalitásnak különbözô szintjei jelennek meg, és az egyes fogyasztói, partneri csoportok eltérô attitúddel bírnak.

\section{A fogyasztói lojalitás vizsgálata a hazai energiaszolgáltatók piacán}

Az empirikus kutatás a hazai energiaszolgáltatók lakossági fogyasztói körében zajlott. Felmerül a kérdés, hogy van-e értelme a lojalitás vizsgálatának kvázi monopolpiacon, illetve szolgálhat-e használható eredményekkel egy olyan kutatás, ahol a vizsgált témában érintettek egyelőre nem igazán kompetensek annak megítélésében, hogy mit is jelent a piacok felszabadítása. Nos, úgy gondoljuk, hogy számos érv sorakoztatható fel a kutatás indokoltsága mellett.

Egyrészt hazánkban a rendszerváltozást követően fokozatosan megtörtént a közüzemi cégek privatizációja, melynek következtében az energiaszektor jelentős része külföldi tulajdonosok kezébe került. Ez a tény komoly kihívást jelentett a korábban egyértelmúen, ma már inkább kvázi monopolhelyzetben lévő szervezetek számára, a privatizáció jelentős fejlesztéseket eredményezett, és megváltoztak a piaci viszonyok is. Az új körülmények között a többnyire továbbra is részleges monopolhelyzetben lévő cégeknek új kihívásokkal kellett szembenézniük, és a hagyományos szemléletet az 1990-es évek második felétől fokozatosan felváltotta a piacorientált szemlélet. Már a privatizáció időszakában versengés alakult ki a szolgáltatás feltételeivel nem kellően ellátott területek megszerzéséért, hamarosan megjelent a verseny a helyettesítô szolgáltatások között (gázfútés-villanyfútés), majd lassan kialakult az azonos szolgáltatások közötti konkurencia is. Mára a piacorientált szemlélet nélkülözhetetlen az energiaszolgáltatók számára, hiszen az uniós csatlakozás komoly követelményeket támaszt a piacok felszabadításával kapcsolatban.

Másrészt megváltozott a fogyasztói magatartás, és a megnőtt a fogyasztói tudatosság. A fogyasztók sokkal több információval rendelkeznek a termékekról, szolgáltatásokról, jobban ismerik jogaikat, és hajlamosabbak érdekeik érvényesítésére, mint korábban (Reketytye, 2000; Hetesi, 2001).

Harmadrészt feltételezzük, hogy az energiapiacok - folyamatban lévő - felszabadítása után azok a szervezetek lesznek versenyelőnyben, amelyek idóben információkat gyújtenek fogyasztóikról, felmérik fogyasztóik attitűdjeit, és megfelelő marketing-stratégiákat tudnak kialakítani a vevőmegtartásra. (Pl.. arra, hogy vajon milyen kínálat mellett pártolnának el tólük a fogyasztók, ha új szolgáltatók jelennek meg a piacon.)

Negyedrészt korábbi kutatásainak alapján úgy gondoljuk, hogy a közüzemi szolgáltatások esetében a lakossági fogyasztói lojalitás dimenziói specialitásokkal bírnak, és a nemzetközileg jól bevált modellek ebben a környezetben és ebben a szférában nem alkalmazhatók automatikusan (Hetesi - Rekettye, 2005/a, 2005/b).

A vizsgálat során kiinduló problémának tekintettük, hogy a liberalizáció folyamatában a cégek számára az egyik legfontosabb kérdés az lesz, hogy miként tudják megtartani fogyasztóikat, miként tudnak kialakítani egy lojális, húséges fogyasztói bázist. Kétségtelen, hogy a liberalizált piacokon a szervezetek többsége a nagyfogyasztók megtartását tûzte ki célul, mások azonban célravezetőnek tartották a lakossági fogyasztókra való odafigyelést is. Megítélésük szerint a lakossági piacon alacsony ugyan a profit, de a hibázási lehetôség is kicsi, és ha van adatbázis a fogyasztókról, akkor nagyobb az esély azok meghódítására, illetve lojalitásuk növelésére (Stagen, 1997; Heath, 1997).

A kutatási modell kialakításánál elsôsorban a szakirodalomban már részben bizonyított összefüggésekre támaszkodtunk (Oliver, 1999; Neal, 1999; Grönholdt et al., 2000), de a vizsgált terület specialitásai és a sajátos magyarországi környezeti feltételek következtében új elemeket is tartalmazott a vizsgálat.

\section{A vizsgálat lebonyolítása \\ és az eredmények értékelése}

A kutatás ezerfős reprezentatív lakossági mintán személyes kérdőíves módszerrel történt a magyarországi áramszolgáltató cégek ellátási területén. A minta kiválasztásához az egyszerú véletlen mechanikus módszert használtuk (minden n-edik módszer), a kérdőíveket előzetesen teszteltük, a kérdezóbiztosok munkáját akik háztartásokat kerestek fel - kitöltési útmutatókkal segítettük. A minta összetétele nemek, életkor, iskolai végzettség, foglalkozás és lakóhely alapján jól tükrözi az alapsokaság jellemzőit.

Az adatállományt az átlagok, szórások, faktorelemzés és regresszióanalízis segítségével is elemeztük (Hetesi - Rekettye, 2005/a, 2005/b), jelen tanulmányban pedig a klaszteranalízis eredményeit vizsgáljuk részletesen.

Az 1. táblázat a faktorelemzés eredményeit mutatja, ahol látható, hogy milyen változókkal vizsgáltuk a lakossági lojalitást az energiapiacon (1. táblázat).

A faktoranalízis eredményei a fentiek alapján nehezen értelmezhetók, így a bizonytalan újraválasztási elem elhagyásával is elvégeztük az elemzést (2. táblázat). 
A lojalitás változó faktorelemzése

\begin{tabular}{|c|c|c|c|}
\hline \multirow{2}{*}{ Kérdés tartalma } & \multicolumn{3}{|c|}{ Faktorok } \\
\hline & 1 & 2 & 3 \\
\hline \multicolumn{4}{|l|}{ Ha az új szolgáltató: } \\
\hline - ugyanolyan feltételekkel kínálná a szolgáltatást, biztosan maradnék a jelenlegi szolgáltatónál & 0,82 & & \\
\hline - jobb tájékoztatást nyújtana, ôt választanám & 0,77 & & \\
\hline - egyszerúbb ügyintézést ígérne, ót választanám & 0,69 & & \\
\hline - 10\%-kal olcsóbban kínálná a szolgáltatást, ôt választanám & & $\mathbf{0 , 9 3}$ & \\
\hline -5\%-kal olcsóbban kínálná a szolgáltatást, ốt választanám & & $\mathbf{0 , 8 6}$ & \\
\hline - szélesebb választékot kínálna, őt választanám & & 0,51 & 0,49 \\
\hline $\begin{array}{l}\text { Ha több más szolgáltató lenne a piacon változatlan feltételekkel, Ön mekkora valószínúséggel } \\
\text { ajánlaná a jelenlegi szolgáltatót ismerôseinek, barátainak? }\end{array}$ & & & 0,90 \\
\hline
\end{tabular}

A szúkítés után a lakossági fogyasztók az árérzékenység és a szélesebb választék felkínálása kapcsán két jellemző faktorba sorolhatók, amelyek tartalmilag elkülönít- hetôk ugyan, de azt mindenképpen jelzik, hogy a lojalitás mérésére - legalábbis az általunk vizsgált szektorban - valószínúsíthetően más elemeket is célszerü használni.

A lojalitás változó faktorelemzése*

\section{Kérdés tartalma}

Faktorok

\begin{tabular}{l|l}
1 & 2 \\
\hline
\end{tabular}

Ha az új szolgáltató:

\begin{tabular}{|c|c|c|}
\hline - 5\%-kal olcsóbban kínálná a szolgáltatást, ôt választanám & $\mathbf{0 , 9 0}$ & \\
\hline - 10\%-kal olcsóbban kínálná a szolgáltatást, ốt választanám & $\mathbf{0 , 8 6}$ & \\
\hline - egyszerúbb ügyintézést ígérne, oót választanám & & $\mathbf{0 , 7 8}$ \\
\hline $\begin{array}{l}\text { - ha több más szolgáltató lenne a piacon változatlan feltételekkel, Ön mekkora valószínúséggel ajánlaná } \\
\text { a jelenlegi szolgáltatót ismerőseinek, barátainak? }\end{array}$ & & $\mathbf{0 , 7 5}$ \\
\hline - jobb tájékoztatást nyújtana, ôt választanám & & $\mathbf{0 , 7 3}$ \\
\hline - szélesebb választékot kínálna, ốt választanám & & $\mathbf{0 , 6 8}$ \\
\hline
\end{tabular}

*az újraválasztási elem elhagyásával

3. táblázat

A vizsgált dimenziók számától függó átlagérték

\begin{tabular}{|c|c|c|c|c|c|c|c|c|c|c|c|c|}
\hline \multirow[b]{3}{*}{ Ugyanolyan feltételekkel } & \multicolumn{12}{|c|}{ ÁTLAG } \\
\hline & \multicolumn{2}{|c|}{ Hezitálók } & \multicolumn{2}{|c|}{ Hútlenek } & \multicolumn{2}{|c|}{ Elégedetlenek } & \multicolumn{2}{|c|}{$\begin{array}{c}\text { Konokul } \\
\text { kitartók }\end{array}$} & \multicolumn{2}{|c|}{ Flegmatikusok } & \multicolumn{2}{|c|}{ Konzervatívok } \\
\hline & 4,99 & 5 & 4,24 & 4,01 & 3,55 & 4,84 & 5 & 5 & 4,98 & 3,41 & 4,97 & 4,71 \\
\hline 5\%-kal olcsóbb & 2,67 & 2,75 & 3,83 & 4,14 & 2,95 & 1,77 & 1,34 & 1,1 & 1,25 & 2,82 & 2,89 & 2,41 \\
\hline 10\%-kal olcsóbb & 4,27 & 4,16 & 4,27 & 4,54 & 3,45 & 3,06 & 2,21 & 1,41 & 1,75 & 3,58 & 4,52 & 3,42 \\
\hline szélesebb választék & 3,2 & 3,48 & 4,24 & 4,47 & 3,09 & 1,97 & 1,5 & 1,08 & 1,12 & 3,18 & 1,72 & 2,5 \\
\hline egyszerúbb ügyintézés & 2,22 & 2,52 & 4,06 & 4,21 & 2,37 & 1,33 & 1,24 & 1,02 & 1,03 & 2,27 & 1,09 & 1,95 \\
\hline jobb tájékoztatás & 1,58 & 1,86 & 3,89 & 3,95 & 2,18 & 1,23 & 1,19 & 1 & 1,02 & 2,07 & 1,03 & 1,7 \\
\hline ajánlaná-e másoknak & 4,43 & & 3,58 & & 3,16 & & 4,56 & & 1,02 & & 1,09 & \\
\hline
\end{tabular}

ötfokozatú skála átlagai, ahol 1 = egyáltalán nem igaz, 5 = nagyon igaz 
1. ábra ketingstratégiát követel, amely

\section{A hezitálók válaszai a változásokra}

\section{Hezitálók}

ugyanolyan feltételekkel marad a jelenlegi szolgáltatónál

10\%-kal olcsóbban az új szolgáltatót választja

szélesebb választék esetén az új szolgáltatót választja

5\%-kal olcsóbban az új szolgáltatót választja

egyszerübb ügyintézés esetén az új szolgáltatót választja

jobb tájékoztatás esetén az új szolgáltatót választja

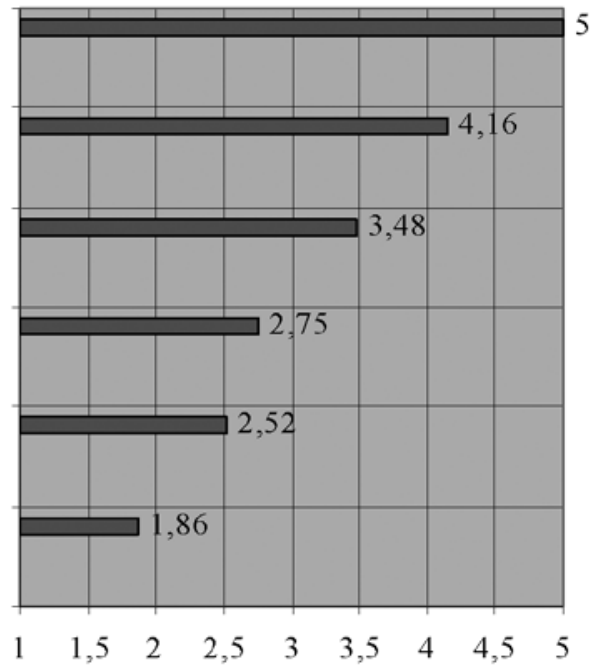

nem nélkülözheti a differenciálást, megközelítésük nehéz, és lojalitásuk kialakításának hatékonysága is bizonytalan (1. ábra).

Hütlenek (105 fö). A csoport tagjai kevésbé elégedettek szolgáltatójukkal, mint az átlag, rendkívül árérzékenyek, és az e klaszterbe tartozók a leginkább nyitottak a szélesebb választék, az egyszerúbb ügyintézés és a jobb tájékoztatás iránt. Szélesebb választék esetén jóval az átlag feletti mértékben pártolnának át az új szolgáltatóhoz, és körükben messze az átlag alatti az azonos feltételekkel megjelenó szolgáltató esetén lojalitást jelzók értéke. A hứtlenek preferálnak minden újdonságot, és esetükben nehéz

A klaszterezést több lépésben végeztük el, végül 6 csoport értelmezése mellett döntöttünk. A 7 változó esetében - ahol a másoknak való ajánlás is szerepel - 794 válaszadót értékelhettünk, amikor a másoknak való ajánlást kihagytuk az elemzésbőll, az értékelhető válaszadók száma 899-re emelkedett. A két eljárás adatai közötti átlagok különbségeit mutatja a 3. táblázat.

A másoknak való ajánlás dimenzió elhagyásával 6 dimenzió mentén a 6 fogyasztói klasztert jelzókkel címkéztük, jellemeztük lojalitási attitúdjeiket, valamint vizsgáltuk szociodemográfiai paramétereiket.

Hezitálók (219 fơ). A klaszter tagjai a lojalitásdimenziók megítélésében „zavaros értékrendúnek” tekinthetốk. Bár ugyanolyan feltételeket kínáló szolgáltató megjelenése esetén biztosan nem váltanának energiaszolgáltatót, valamint 5\%-os árcsökkentésre sem érzékenyek, bizonyos változások esetén elpártolnának jelenlegi szolgáltatójuktól. A klaszterbe tartozók 10\%-os ármérséklés esetén már jelentôs hajlandóságot mutatnak a váltásra, és a szélesebb választék iránt is nyitottnak mutatkoznak. Ugyanakkor csekély érdeklődést tanúsítanak az egyszerúbb ügyintézés iránt, az új szolgáltató jobb tájékoztatási tevékenysége pedig alig mozdítja el óket a jelenlegi szervezettól, azaz az egyszerúbb ügyintézés és a jobb tájékoztatás felajánlása az új szolgáltató részéról nem elegendô az elcsábításukra. A hezitálók körében az átlagosnál nagyobb arányban jelennek meg a 2-3 fős háztartások, a 30-45 év közöttiek és a szakmunkásképzốt végzettek, míg a felsőfokú végzettségúek és a 60 évnél idősebbek értékmutatója alacsonyabb, mint az átlag. E csoport tagjainak megtartása olyan célzott mar- lesz olyan kínálattal fellépni, amely visszatartja óket a váltástól. Feltehetően az „újra nyitottak” kategóriájával találjuk szembe magunkat, akik szabad választás esetén mérlegelés helyett inkább „kalandorokként” viselkednek majd, és megpróbálják kihasználni a lehetőségeket. A klaszterbe tartozók között az átlagosnál jóval nagyobb értékmutatóval jelennek meg a 6 fós vagy annál nagyobb létszámú háztartások, a 30 év alattiak, az egyetemet, fớiskolát végzettek, a fóvárosiak és a nốk. Ugyanakkor a hứtlenek között kevés a 60 év feletti, alacsony a 8 általánost, vagy annál kevesebbet végzettek aránya, valamint a községekben élók értékmutatója. A csoport szociodemográfiai jellemzói alapján rendkívül eklektikus szegmenssel állunk szemben, hiszen a nagy létszámú háztartások esetében általános elégedetlenségre, a fiatalok körében az újra való nyitottságra, a diplomásoknál a fokozottabb fogyasztói tudatosságra, a fővárosiaknál az erôteljesebb érdekérvényesítési képességre kell különös figyelmet fordítani. E klaszter kapcsán sem egyszerú olyan marketingeszköztár felvonultatása, amely alkalmas a hatékony vevőmegtartásra (2. ábra).

„Elégedettek, „minden mindegy attitüd” (220 fó). A klaszter tagjai nem változtatnának szolgáltatót, ha a versenytárs ugyanolyan feltételekkel jelenne meg a piacon, árérzékenységük is alacsonyabb, mint az átlag. Az új szolgáltató 5\%-os árengedménye nem tántorítaná el óket jelenlegi szolgáltatójuktól, és a drasztikusabb árengedmény sem rendítené meg jelentősen húségüket. A jobb szolgáltatásjellemzókre nem nyitottak, a hatékonyabb tájékoztatás és az egyszerúbb ügyintézés alig 


\section{A hútlenek válaszai a változásokra}

\section{Hütlenek}

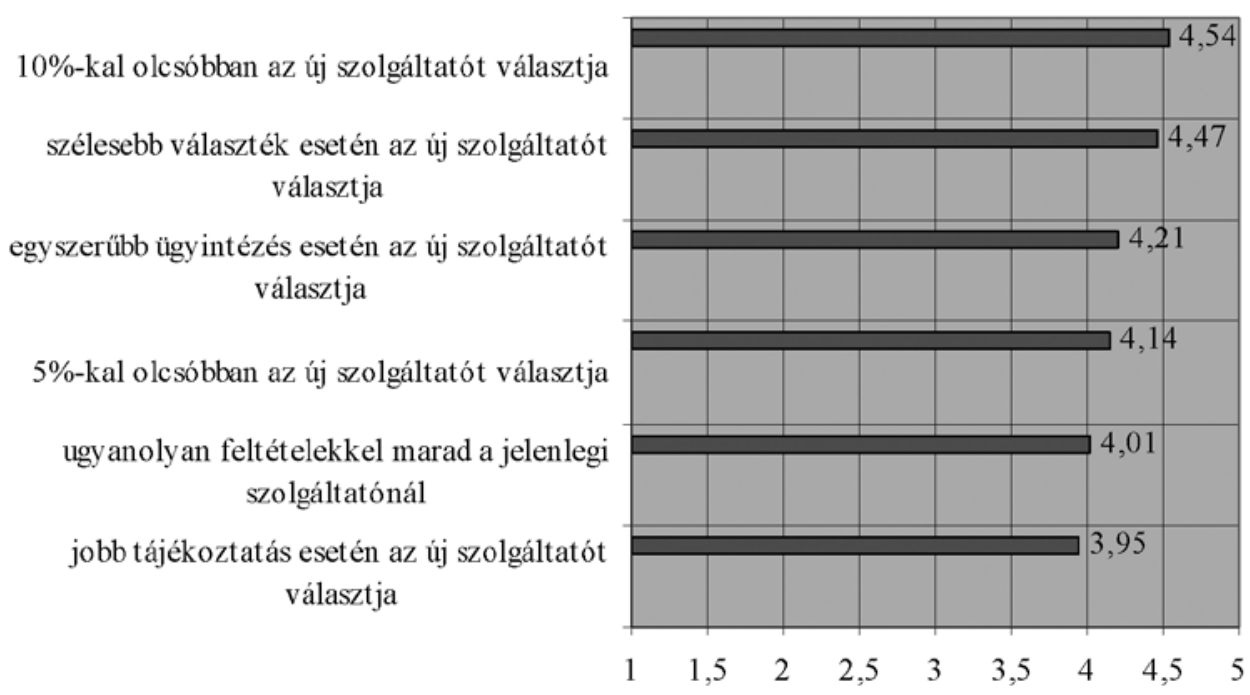

értékmutatóval jelennek meg ebben a csoportban. (A kereszttáblák alapján fontos megjegyezni, hogy a 60 év felettiek általában egy fôs háztartásokban élnek.) Érdekes, hogy a konokul kitartók között a felsőfokú végzettséggel rendelkezôk értékmutatója is meghaladja az átlagot, ami vagy a liberalizációt illető nagyobb rálátással, vagy egyfajta távolságtartó magatartással magyarázható (4. ábra).

Flegmatikusok (74 fó) A klaszterbe tartozók érzékenysége a váltásra közepes, a felkínált lehetôségekkel kapcsolatban szkeptikusak. Az átlagosnál érintené döntéseiket, a szélesebb választék iránti érdeklôdésük is csekély. Ôk azok, akik kevés ráfordítással megtartható, lojális fogyasztói bázist képezhetnek az energiaszolgáltatók számára. Szociodemográfiai jellemzőik többnyire leképezik az átlagot, bár némiképpen felülreprezentáltak a 46-60 év közöttiek (3. ábra).

Konokul kitartók (181 fó). A klaszter tagjai maximálisan elégedettek jelenlegi szolgáltatójukkal, ugyanolyan feltételekkel megjelenô új szolgáltató esetén egészen biztosan maradnának a jelenleginél, és semmilyen változtatásra nem érzékenyek. Körükben még a 10\%-os árcsökkentés sem eredményezne számottevô elmozdulást, az 5\%-os ármérséklésre szinte egyáltalán nem reagálnak, és teljes elutasítás tapasztalható az újításokkal kapcsolatban. E csoportban olyan mértékú az átlag feletti elutasítás az új szolgáltató megjelenésével kapcsolatban, hogy a szegmens megnyerésére tett erófeszítések felesleges pénzkidobást jelentenének az energiaszolgáltatók számára. A klaszter szociodemográfiai összetételét illetően megállapítható, hogy itt a legmagasabb a 60 év felettiek aránya, és az egyfős háztartások magasabb jóval elégedetlenebbek jelenlegi szolgáltatójukkal, és ha ugyanilyen feltételekkel jelenne meg az új szolgáltató, azt is kellő fenntartással fogadnák. Árérzékenységük alacsonyabb, mint az átlag, az újításokra mérsékelten nyitottak, a felajánlásokat és lehetôségeket mintegy elutasítva rezignáltan reagáltak a kérdésekre. A klaszterben felülreprezentál-tak a nagycsaládosok, a 30 évnél fiatalabbak, a szakmunkásképzőt végzettek és a községekben élók. A szociodemográfiai jellem-

\section{Az elégedettek válaszai a változásokra}

3. ábra

Eégedettek

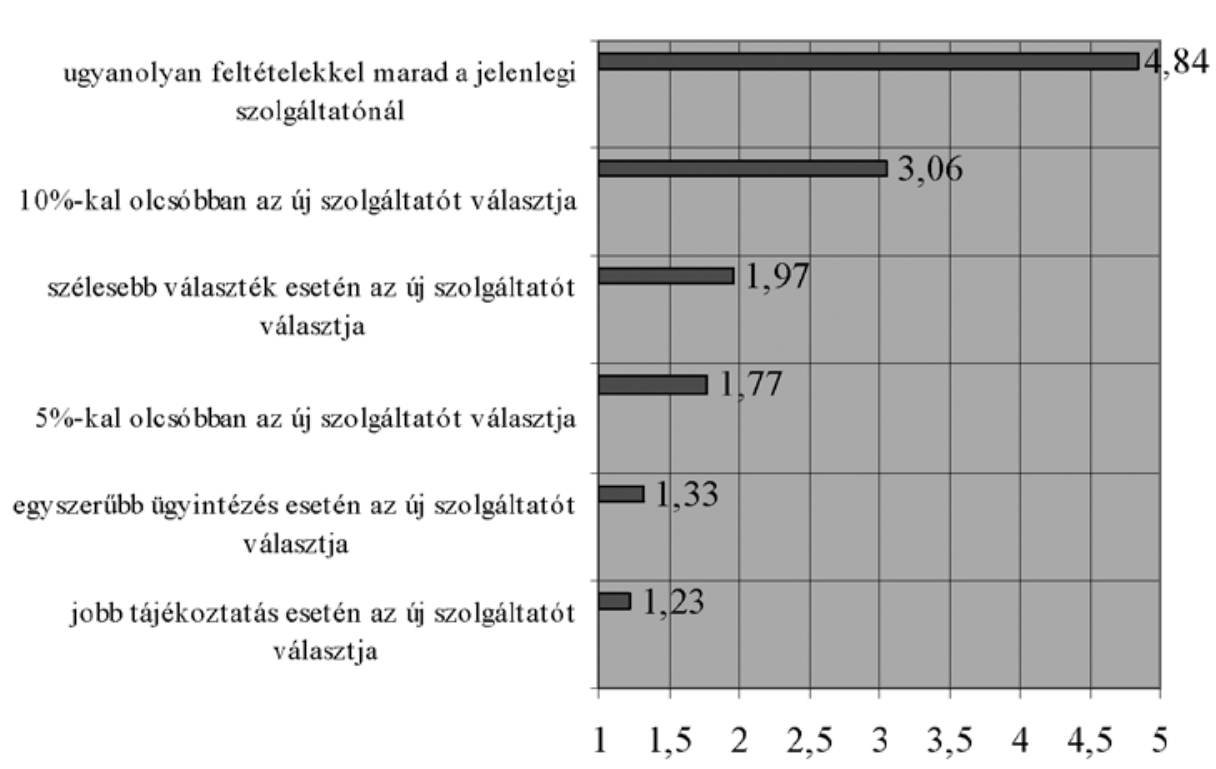

$\begin{array}{lllllllll}1 & 1,5 & 2 & 2,5 & 3 & 3,5 & 4 & 4,5 & 5\end{array}$

\section{VEZETÉSTUDOMÁNY}



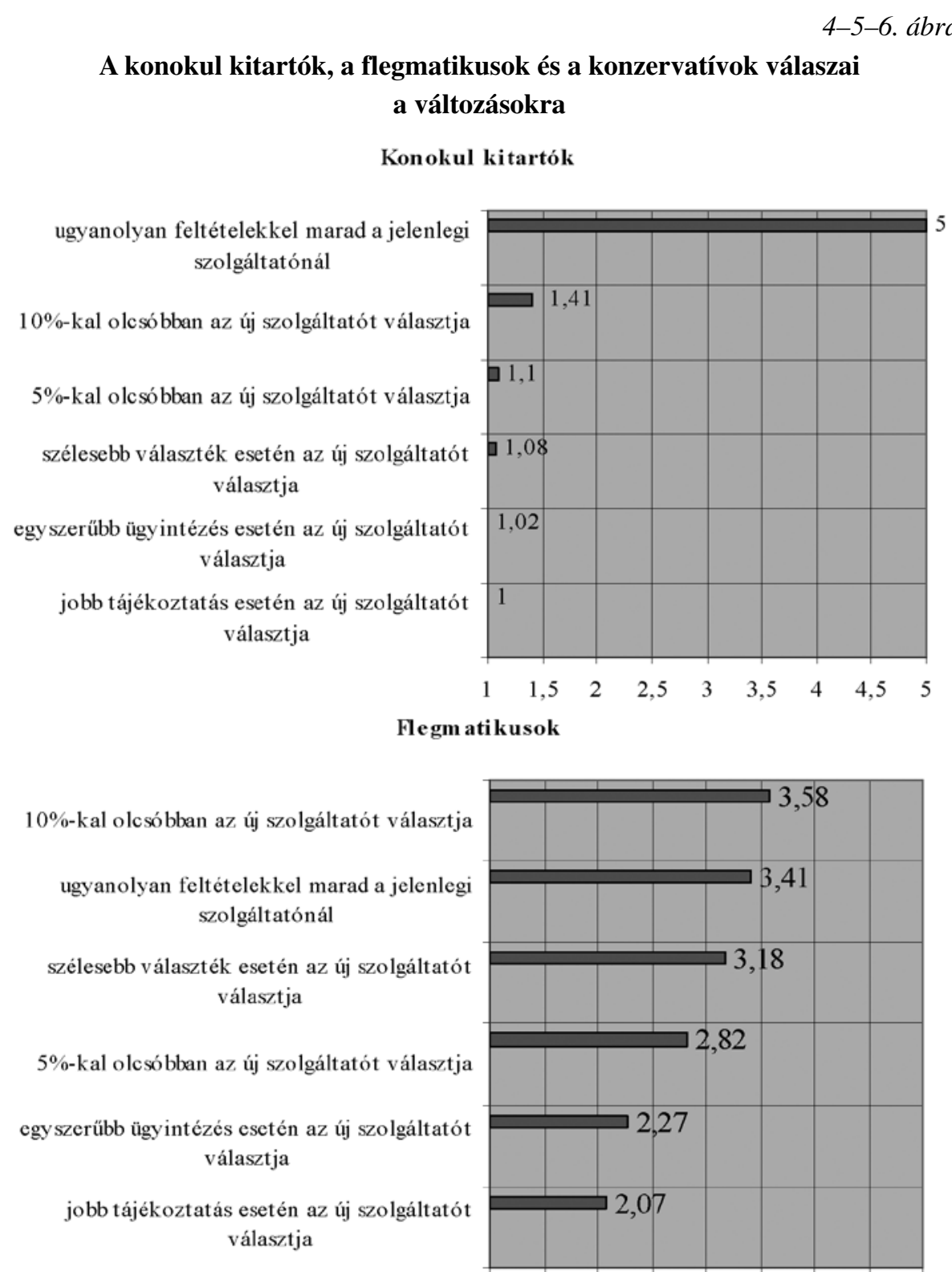

Konzervativok

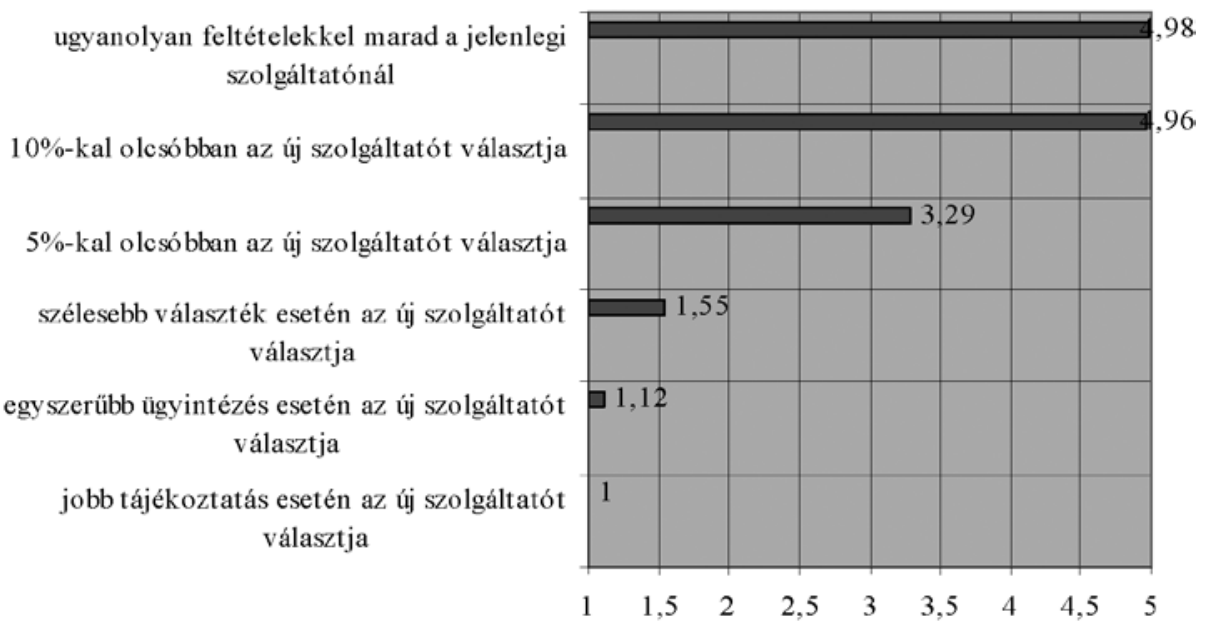

zốk alapján szegmensspecifikus marketingstratégia kidolgozására van szükség a réteg lojalitásának megnyerésére. A csoport tagjainak megnyerése a húségre speciális marketing stratégiát igényel, ốk azok, akiket attitűd alapján a szakirodalom a közömbösök kategóriájába sorolja, és akikkel kapcsolatban a legnehezebb hatékony marketingstratégiát kidolgozni (5. ábra).

Konzervatívok (100 fó). A csoport tagjai nagyon elégedettek jelenlegi szolgáltatójukkal, és bár árérzékenyek, az újdonságokra nem fogékonyak. Jelentôs árcsökkenés felkínálása esetén átpártolnának az új szolgáltatóhoz, de az 5\%-os mérséklés nem igazán rendítené meg lojalitásukat a jelenlegi szervezethez. A szélesebb választék felkínálása igen kis mértékben befolyásolja a konzervatív fogyasztók választását, az egyszerúbb ügyintézés sem vonzza ezeket a fogyasztókat, a jobb tájékoztatásra pedig teljesen érzéketlenek. A klaszterben felülreprezentáltak a 60 év felettiek, az átlagosnál magasabb az egyfős háztartások aránya, kissé magasabb értékmutatóval jelennek meg az érettségivel és egyetemi végzettséggel rendelkezók, míg a fóvárosban élő́k aránya ebben a csoportban alacsonyabb, mint az átlag. E klaszter tagjainak megtartása is differenciált marketing stratégiát követel, de körükben célszerú az ármarketing átgondolása (6. ábra).

\section{Empirikus kutatás a B2B piacon}

A B2B-piacon a partneri lojalitást, ragaszkodást befolyásoló tényezók meghatározására kvalitatív és kvantitatív módszerekkel kombinált kutatást végeztünk. A lojalitást az aláb- 
biakban határoztuk meg: lojális az a partner, aki elkötelezett a szállító iránt, kisebb elégedetlenség és a versenytársak által felkínált kisebb árengedmények esetén nem hagyja el beszállítóját, és (tovább) ajánlja azt más vevốknek is, továbbá aktív együttmúködő.

Kutatási modellünk kiindulópontját azok az elméleti megközelítések és empirikus vizsgálati eredmények jelentették, amelyek felhívták a figyelmet arra, hogy a fogyasztói lojalitás mérési dimenziói nem sztandardizálhatók, a dimenziók és azok meghatározó ereje függ a vizsgált ágazattól, terméktól, szolgáltatástól (Oliver, 1997; Edvardsson et al., 2000; Costabile, 2000; Rekettye - Hetesi, 2001). További támpontul szolgáltak a B2B-lojalitás szakirodalmi előzményei, és a fogyasztói lojalitástól eltérô tényezók szerepeltetése az elméleti és empirikus vizsgálati modellekben (Geyskens - Steenkamp, 1995; Meyer - Allen, 1991; Elliott - Glynn, 2000; Yanamandram - White, 2006) Az általunk definiált lojalitás dimenzióit a lojalitás és a minőség-elégedettség-lojalitás-jövedelmezőség lánc értelmezésén, a kapcsolatiság, az elégedetlenség ellenére való ragaszkodás és a bizalom dimenzióin keresztül mértük.

\section{A kvantitatív kutatás lebonyolítása és eredményei}

A kvantitatív felmérés kérdéseit az előzetes kvalitatív kutatás következtetéseire építettük, és ennek megfelelően finomítottuk a mérési dimenziókat (Hetesi - Veres, 2004). A mérés egy moduláris állítássorozat válaszadói elfogadásának mértékén alapult. A kérdőíves vizsgálat (nettó) 105 partnercégre terjedt ki, ahol a kiválasztásnál figyelembe vettük a cégek telephelyét, a megkérdezés pedig telefonos interjúkkal történt. Öszszesen 31 változót dolgoztunk fel, a kérdések faktoranalízise 12 faktort emel ki a lojalitás magyarázatából (4. táblázat).

A 12 faktorból 8 elemzését tartottuk célszerúnek, és ezek a következók:

- személyes találkozások (hangulata, gyakorisága, empátia, rugalmasság),

- régi jó kapcsolat (jó kapcsolat a vezetókkel, a kapcsolattartókkal, érzelmi elkötelezettség, kockázat az új partnert illetően),

- feltétlen bizalom (igazmondás, titoktartás, ígéretek betartása, lehetetlen kérések teljesítése),

- abszolút húség (kisebb árkedvezmények miatt nem pártol el, hosszú évekig nem vált partnert).),

- számíthatunk rájuk (segítôkészség, együttérzés a bajban, nem hagynak cserben, mindig számíthatunk a többletteljesítésre),
4. táblázat

A magyarázott variancia

\begin{tabular}{|c|c|c|c|}
\hline \multirow{2}{*}{ Faktorok } & \multicolumn{3}{|c|}{ Rotáció utáni magyarázott variancia } \\
\cline { 2 - 4 } & Saját érték & $\begin{array}{c}\text { Magyarázott } \\
\text { variancia }\end{array}$ & $\begin{array}{c}\text { Kumulált } \\
\text { variancia }\end{array}$ \\
\hline 1 & 7,584 & 20,496 & 20,496 \\
\hline 2 & 3,424 & 9,253 & 29,749 \\
\hline 3 & 2,698 & 7,291 & 37,041 \\
\hline 4 & 2,090 & 5,650 & 42,690 \\
\hline 5 & 1,895 & 5,120 & 47,810 \\
\hline 6 & 1,763 & 4,766 & 52,576 \\
\hline 7 & 1,644 & 4,443 & 57,020 \\
\hline 8 & 1,494 & 4,038 & 61,058 \\
\hline 9 & 1,292 & 3,491 & 64,549 \\
\hline 10 & 1,169 & 3,159 & 67,708 \\
\hline 11 & 1,081 & 2,921 & 70,629 \\
\hline 12 & 1,004 & 2,712 & 73,341 \\
\hline
\end{tabular}

- aktív húség (elégedetlenség mellett is marad, másoknak is ajánlja a beszállítót, mást is vásárol),

- összejövetelek szerepe (hasznosak, hangulatosak, növelik a húséget),

- passzív húség, vagy „tehetetlenség” (kockázat, a váltás költségei, a kényelem).

$\mathrm{Az}$ általunk tartalmilag jól értelmezhető faktorok együttes magyarázó ereje $61 \%$, azaz az első nyolc faktor ennyiben magyarázza a partneri húséget. Figyelemre méltó, hogy a kapcsolatokat, a bizalmat, az empátiát, megértést megjelenítő első 5 faktor közel felét magyarázza a húségnek, azaz az éles piaci versenyben az árak mellett e tényezôknek jelentôs szerepük van a lojális vevői bázis kialakításában. Az utolsó négy faktor tartalmilag ellentmondásosnak bizonyult, ezért ezeket kihagytuk az elemzésból.

\section{A lojalitásdimenziók klaszterelemzése}

A lojalitási dimenziók előzőekben leírt feltárását követően a kutatás legfontosabb céljához, a lojalitási csoportok azonosításához érkeztünk. A 31 változó soknak bizonyult a klaszterek kialakítására, így az eredeti változókat csoportosítottuk, és a 8 lojalitásfaktorral dolgoztunk tovább. Miután az első 8 faktor $61 \%$-os magyarázó eróvel bír, így elegendőnek tekintettük az elemzéshez.

A klaszterelemzést itt is több lépcsóben végeztük el, és végül három jól leírható klasztert találtunk a vizsgált változók alapján. A feldolgozás során alaptétel volt, hogy csak azok a válaszadók kerüljenek be a vizsgálat- 
ba, akik valamennyi kérdésre válaszoltak, így 42 partner besorolására volt lehetóségünk a tipikus válaszok alapján, azaz a minta 60\%-a kiesett az elemzésból. Az elemzés alapján a következô három klasztert találtuk (5. és 6. táblázat): fontos a lojalitás szempontjából az igazmondás, a titoktartás, az ígéretek betartása. A feltétlen bizalom mellett fontos, hogy a beszállító a lehetetlen kérések teljesítését is próbálja megoldani, azaz az odaadó húség ára a bizalom és a beszállító rugalmassága, figyelmessége.

5. táblázat

Klaszterek a partneri piacon

\begin{tabular}{|l|c|c|c|c|c|}
\hline \multicolumn{7}{|c|}{ Ward módszer } \\
\hline \multirow{3}{*}{ Klaszterek } & & gyakoriság & \% & Megoszlás \% & Kumulativ \% \\
& $\mathbf{1}$ & 14 & 13,3 & 33,3 & 33,3 \\
\cline { 2 - 7 } & $\mathbf{2}$ & 17 & 16,2 & 40,5 & 73,8 \\
\cline { 2 - 7 } & $\mathbf{3}$ & 11 & 10,5 & 26,2 & 100,0 \\
\cline { 2 - 7 } & Összes & 42 & 40,0 & 100,0 & \\
\hline Hiányzó adatok & & 63 & 60,0 & & \\
\hline Összesen & & 105 & 100,0 & & \\
\end{tabular}

Az első klaszterben 14 partner szerepel, a vizsgálaba bevont minta 33\%-a, a másodikban 17 vevôvel 41\%kal jelennek meg a partnerek, míg a harmadik 26\%-os aránnyal 11 vevốt reprezentál. A klaszterjellemzóket a faktorpontok alapján hasonlítottuk össze.
Mérsékelten lojálisak(17 szervezet, 41\%). A klaszter tagjai a régi jó kapcsolatra alapozzák húségüket a beszállítóhoz, mindössze e kérdésben találunk a faktorátlagnál kiemelkedően magas értéket. Lojalitásfelfogásuk visszafogottabb az előző klaszterben szereplőknél, ná-

Klaszterek a faktorpontok alapján

\begin{tabular}{|c|c|c|c|c|c|c|c|c|c|}
\hline $\begin{array}{c}\text { Ward } \\
\text { Method }\end{array}$ & & $\begin{array}{c}\text { Személyes } \\
\text { találkozás }\end{array}$ & $\begin{array}{c}\text { Régi jó } \\
\text { kapcsolat }\end{array}$ & $\begin{array}{c}\text { Feltétlen } \\
\text { bizalom }\end{array}$ & $\begin{array}{c}\text { Abszolút } \\
\text { húség }\end{array}$ & $\begin{array}{c}\text { Számítha- } \\
\text { tunk rájuk }\end{array}$ & $\begin{array}{c}\text { Aktív } \\
\text { húség }\end{array}$ & $\begin{array}{c}\text { Összejöve- } \\
\text { telek szerepe }\end{array}$ & $\begin{array}{c}\text { Passzív } \\
\text { hússég }\end{array}$ \\
\hline \multirow{2}{*}{$\mathbf{1}$} & Átlag &,- 17 &,- 36 &, 37 &, 55 &, 29 &, 64 &,- 34 &,- 43 \\
\cline { 2 - 11 } & $\mathbf{N}$ & 14 & 14 & 14 & 14 & 14 & 14 & 14 & 14 \\
\hline \multirow{2}{*}{$\mathbf{2}$} & Átlag &,- 61 &, 60 &,- 74 &,- 31 &,- 53 &,- 005 &,- 20 &,- 08 \\
\cline { 2 - 11 }$y$ & $\mathbf{N}$ & 17 & 17 & 17 & 17 & 17 & 17 & 17 & 17 \\
\hline \multirow{2}{*}{3} & Átlag &, 62 &, 32 &, 36 &, 023 &, 52 &,- 085 &, 19 &, 82 \\
\cline { 2 - 11 }$y$ & $\mathbf{N}$ & 11 & 11 & 11 & 11 & 11 & 11 & 11 & 11 \\
\hline \multirow{2}{*}{ Total } & Átlag &,- 14 &, 21 &,- 083 &, 06 &, 015 &, 19 &,- 14 &, 04 \\
\cline { 2 - 11 } & $\mathbf{N}$ & 42 & 42 & 42 & 42 & 42 & 42 & 42 & 42 \\
\hline
\end{tabular}

Odaadóan hüségesek (14 szervezet, 33\%). Ebben a klaszterben olyan partnerek jelennek meg, akik preferenciáiban a faktorátlagok magasabbak az aktív hưség, az abszolút húség és a feltétlen bizalom tekintetében, míg a passzív húség, a kapcsolat elótörténete, az öszszejövetelek és a személyes találkozások szerepe csekélyebb szerepet játszanak a lojalitásban. A klaszter tagjaira jellemző, hogy elégedetlenségük ellenére is nehezen mozdulnak, hosszú évekig nem váltanak partnert, és jelenlegi beszállítójukat másoknak is ajánlják. Tartanak a váltás kockázatától, jelentősebb árkedvezmény hatására sem váltanának partnert, és számukra nagyon luk ugyanis a faktorértékek néhány esetben alacsonyabbak, mint az átlag. Ragaszkodásukat jelenlegi beszállítójukhoz alig befolyásolják a személyes találkozások, az összejövetelek szerepe is csekély, és érdekes, hogy a bizalom is kisebb súllyal szerepel lojalitásukban. A feltétlen bizalom faktor alacsony pontértéke arra utal, hogy a mérsékelten lojális klaszter tagjai kevésbé tartanak igényt az igazmondásra, az ígéretek betartására, feltehetően azért, mert a régi jó kapcsolat miatt számukra ezek a tényezók természetesek. Jó a kapcsolatuk a vezetôkkel, a kapcsolattartókkal, érzelmi elkötelezettséget is jeleztek, így az „,egyenértékúség” érzése olyan 
biztonságot jelent számukra, ami mellőzheti az odaadó húség kinyilvánítását.

Kapcsolatorientáltak (11 szervezet, 26\%). A harmadik klaszterben olyan partnerek jelennek meg, akik számára kiemelkedô szerepe van a húségben a kapcsolatok ápolásának, azaz a faktorpontok magasabbak a személyes találkozás, a feltétlen bizalom, a számíthatnak a beszállítóra, az abszolút húség és a régi jó kapcsolat dimenziókban. Ez a klaszter képezi le leginkább a partnerek pszichológiai kötődését, és jelzésértékú az is, hogy a passzív húség kapcsán a faktorátlag itt a legmagasabb, azaz feltételezhetô, hogy a vevő azért lojális, mert kedveli a kapcsolattartót. Erre utal, hogy a csoporttagok nagy jelentőséget tulajdonítanak a személyes találkozások gyakoriságának, azok hangulatának, a kapcsolattartó rugalmasságának és empátiájának. Hasonlóan fontos számukra az igazmondás és a titoktartás, valamint, hogy a lehetetlen kéréseket is próbálja megoldani a beszállító. Ebben a klaszterben találjuk azokat, akik lojalitásuk feltételeként említik a segítókészséget, az együttérzést a bajban, azt, hogy a beszállító nem hagyja cserben a vásárlót, és mindig számíthatnak a többletteljesítésre. A kapcsolatorientáltakat jelentôsebb árkedvezmények sem tántorítanák el jelenlegi beszállítójuktól, jó a kapcsolatuk a vezetókkel, a kapcsolattartókkal, és érzelmi elkötelezettséget is jeleztek.

\section{Összegzés, gyakorlati hasznosíthatóság, további kutatási irányok}

Empirikus kutatásaink eredményei megerôsítették azon álláspontokat, melyek szerint a lojalitás mérési dimenzióit másként kell értelmeznünk a fogyasztói és a B2B-piacokon, valamint rávilágítanak arra a tényre, hogy a fogyasztói piacokon belül is lehetnek olyan specialitásai a húségnek, amelyek a lojalitásmérési modellek finomítását igénylik. Módszertani szempontból fontos eredménynek tartjuk annak beigazolódását, hogy a közüzemi szolgáltatási piacon a klasszikus termékekhez képest más változók is szerepet játszanak a fogyasztói lojalitás kialakításában, a B2B piacon pedig a klaszterek jelzik, hogy a partneri húség dimenziói eltérô súllyal jelennek meg a vásárlóknál.

A vizsgálat eredményei számos tanulsággal szolgálhatnak a menedzsment számára is: a liberalizálódó energiapiacon a lakossági fogyasztók megtartása olyan speciális marketingstratégiákat igényel, amelyek figyelembe veszik a piacok szegmentálódását, és az eltérô attitúddel rendelkező fogyasztói csoportok szociodemográfiai jellemzói alapján differenciált eszköztárat alkalmaznak. A B2B-piacon a menedzsment számára hasznos információkkal szolgálhatnak a csoportok eltérő viszonyulásai a beszállítóhoz, és a bizalom jelentőségének igazolása az egyes klaszterekben.

A vizsgálat eredményei ugyanakkor arra is figyelmeztetnek, hogy további longitudinális kutatásokra van szükség ahhoz, hogy megállapításainkat megbízhatónak tekinthessük. Az energiapiac lakossági fogyasztóinak faktorelemzése alapján látható, hogy a lojalitás-dimenziók szúknek bizonyultak a húség megközelítésére, a B2Bpiacon pedig más ágazatokban is szükséges a vizsgálat lebonyolítása, hogy következtetéseinket ellenőrizzük. Úgy túnik, hogy a kutatásmódszertan is felülvizsgálatra szorul. A jövóben szükséges lesz kvalitatív vizsgálatok alkalmazása is, hogy a mögöttes fogyasztói és partneri lojalitásattitúdöket mélyebben megismerhessük.

\section{Lábjegyzet}

Hatékonyabban kell végrehajtaniuk az Európai Unió tagországainak a gáz- és árampiacok megnyitásáról rendelkezô uniós irányelvet, miután annak teljesítésében az Európai Bizottság súlyos fennakadásokat állapított meg. A bizottság egyúttal keményebb lépésekkel fenyegette meg azokat a EU-tagállamokat, amelyek nem tesznek eleget az uniós növekedést és versenyképességet szolgáló liberalizációval kapcsolatos előírásoknak. A bizottság egyebek között azt kifogásolja, hogy a fogyasztóknak a helyi szolgáltatókkal szemben sok esetben még nincs igazi választási lehetőségük. A vizsgálat szerint a gázpiacok a legtöbb tagországban koncentráltak maradtak, és nem sokkal jobb a helyzet az árampiacokon sem: a tagországok nagy részében a piac legalább 75 százaléka a három legnagyobb szolgáltatóé. A kisfogyasztók és a lakosság nagy része megfelelő alternatívák hiányában legalábbis habozik a szolgáltatóváltással, különösen az áram esetében. A bizottság azt is bejelentette: országspecifikus vizsgálatokat kezd a piacnyitással kapcsolatos lépések teljesüléséról és hatékonyságáról, és a jövố év végére újabb jelentést tesz közzé a helyzetról, illetve szükség esetén ajánlásokat is. (Veres, B. 2005: Az energiapiac felszabadítását sürgeti az Európai Bizottság MTI)

\section{Felhasznált irodalom}

Andersen, P.H. - Kumar, R. (2006): Emotions, Trust and Relationship Development in Business Relationship: A Conceptual MODEL FOR Buyer-Seller Dyads. Industrial Marketing Management, Vol. 35. No. 4. pp. 522-535.

Anderson, J.C. - Narus, J. A. (1984): A Model of Distributor's Perspective of Distributor-Manufacturer Working Relationships. Journal of Marketing, Fall, pp. 62-74.

Anderson, J.C. - Narus, J. A. (1990): A Model of Distributor Firm and Manufacturer Firm Working Relationships. Journal of Marketing, January, pp. 44-53.

Aydin, S. - Ozer, G. (2005): The Analysis of Antecedens of Costumer Loyalty in the Turkhish Mobile Telecommunication Market. European Journal of Maketing, Vol. 39. No. 7/8. pp. 910-925. 
Blanchard, K. - Bowles, S.M. (1993): Raving Fans: A Revolutionary Approach To Customer Service, Hardcover, May 19.

Burt, R. S. (1992): Structural Holes: The Social Structure of Competition, Cambridge (Mass.), Harvard University Press

Burt, R.S. - Minor, M.J. (eds.) (1982): Applied Network Analysis: Structural Methodology for Empirical Social Research, Beverly Hills (CA), Sage

Caruana, A. (2004): The Impact of Switching Costs on Customer Loyalty: A Study among Corporate Customers of mobile Telephony. Journal of Targeting, Measurement and Analysis for Marketing, Vol. 12. No. 3. pp. 256-258.

Cary, W. (1999): Customer satisfaction and customer loyalty are the best predictors of customer retention. Adams Six Sigma, 6Q

Colgate, M. - Norris, M. (2001): Developing a Comprehensive Picture of Service Failure. International Journal of Service Industry Management, Vol. 12. No. 3-4. pp. 215-234.

Costabile, M. (2000): A dynamic model of customer loyalty. IMP Conference Proceedings, Bath, U.K.

Day, R.L. (1984): Modelling Choices among Alternative Responses to Dissatisfaction. In Kinnear, T.C. (Eds.) Advances in Consumer Research, Vol. 11. pp. 496-499.

Deming, W.E. (1986): Out of the Crisis. Cambridge, MA: Massachusetts Institute of Technology Center for Advanced Engineering Study. (In: Oliver, 1999.)

Dwyer, F.R. - Schurr, P.H. - Oh, S. (1987): Developing Buyer and Seller Relationships. Journal of Marketing, April, pp. 1-27.

Edvardsson, B. - Johnson, M.D. - Gustafsson, A. - Stranvik, $T$. (2000): The effects of satisfaction and loyalty on profits and growth: products versus services. Total Quality Management, Vol. 11. No. 7. pp. 917-927.

Elliot, G. - Glynn, W. (2000): Segmenting Industrial Buyers by Loyalty and Value. IMP Conference Proceedings, Bath, U.K.

Evans, R.K. - Crosby, A. L. (1988): A Theoretical Model of Interpersonal Relational Quality in Enduring Service Sales Relationships. AMA, New York, In: Kandampully, 1998.

Ford, D. (1980): The Development of Buyer-Seller Relationships. European Journal of Marketing, Vol. 14. pp. 339-354.

Fornell, C. - Wernerfelt, B. (1987): Defensive Marketing Strategy by Customer Complaint Management. Journal of Marketing Research, Vol. 24. Nov. pp. 337-346. (In: Oliver, 1999.)

Ganesan, S. (1994): Determinants of Long-Term Orientation in Buyer-Seller Relationships. Journal of Marketing, Vol. 58. Apr. pp. 1-19.

Garbarino, E. - Johnson, M.S. (1999): The Different Roles of Satisfaction, Trust, and Commitment in Customer Relationships, Journal of Marketing, Vol. 63. No. 2. pp. 70-87.

Geyskens, I. - Steenkamp, J.B. (1995): An Investigation into the Joint Effects of Trust and Interdependence on Relationship Commitment. EMAC Conference Proceedings, Paris, Group ESSEC, pp. 351-371.
Granovetter, M. (1985): Economic Action and Social Structure: the Problem of Embeddedness. American Journal of Marketing Research, pp. 132-141.

Grönholdt, L. - Martensen, A. - Kristensen, K. (2000): The relationship between customer satisfaction and loyalty: cross-industry differences. Total Quality Management, Vol. 11. No. 4/5\&6, pp. 509-514.

Gruen, T.W. (1995): The Outcome Set of Relationship Marketing in Consumer Marketing. International Business Review, No. 4. pp. 447-469.

Hakansson, H. - Osteberg, C. (1975): Industrial Marketing: An Organizational Problem? Industrial Marketing Management, No. 4. pp. 113-123.

Heath, R.P. (1997): The marketing of power. American Demographics, US. 1997/ 9. Vol. 19. Issue 9. p. 59, p. 5.

Hetesi, E. (2001): A marketing munka dolgozói megítélésének, valamint a lakossági fogyasztók lojalitásának mérése és elemzése a hazai közüzemi szolgáltatások körében. Ph.D disszertáció, PTE, KTK

Hetesi, E. - Rekettye, G. 2005/a: A lojalitási dimenziók longitudinális mérése a hazai lakossági energiafogyasztók körében faktoranalízis alapján. Vezetéstud., 2005. 3. sz. pp. $48-57$.

Hetesi, E. - Rekettye, G. 2005/b: A lojalitási dimenziók longitudinális mérése a hazai lakossági energiafogyasztók körében az átlagok alapján. Marketing \& Menedzsment, 2004/6.-2005/1. szám, pp. 55-69.

Hetesi, E. - Veres, Z. (2004): An empirical investigation on loyalty - The case of packaging industry, in: IMP Proceedings, Copenhagen, p. 34.

Hirschman, A.O. (1970): Exit, Voice, and Loyalty-Responses to Decline in Firms, Organizations, and States. Cambridge, MA: Harvard University Press

Hofmeister-Tóth, Á. - Simon, J. - Sajtos, L. (2003): Fogyasztói elégedettség, Alinea Kiadó, Budapest

Huppertz, J.W. - Arenson, S.J. - Sidney J. - Evans, R.H. (1978): An Applications of Equity Theory to BuyerSeller Exchange Situations. Journal of Marketing Research, Vol. 15. pp. 250-260.

Jaishankar, G. - Mark, J.A.\& Kristy, E. Reynolds (2000): Understanding the Customer Base of Service Providers: An Examination of the Differences Between Switchers and Stayers. Journal of Marketing, Vol. 64. pp. 65-87.

Jakoby, J. - Chestnut, R.W. (1978): Brand Loyalty. Measurement and Management, New York, Wiley

Jones, T.O. - Sasser, Jr. W.E. (1995): Why satisfied customer defect? Harvard Business Review, Nov/Dec, Vol. 73. Issue 6.

Kandampully, J. (1998): Service quality to service loyalty: A relationship which goes beyond customer services. Total Quality Management, Vol. 9. Issue 6, p. 431.

Keenan, B. (2000): Customer satisfaction surveys miss the mark. Sales\&Marketing, 20. March, p. 20.

Lam, S.Y. - Shankar, V. - Erramilli, M.K. - Murthy, B (2004): Customer Value, Satisfaction, Loyalty, and Switching Cost: An Illustration From a Business-to Business Serv- 
ice Context . Journal of the Academy of Marketing Science, Vol. 32. No. 3. pp. 113-130.

Lee, M. - Cunningham, L.F. (2001): A Cost/Benefit Approach to Understanding Service Loyalty. Journal of Service Marketing. Vol. 15, No. 2. pp. 113-130.

Lindgreen, A. (2000): The Emergence and Rise of Relationship Marketing: An Empirical Investigation that seeks to describe and explore particular aspects of Relationship Marketing in the International Food and Wine Industries. Université Catholique de Louvain, Denmark

Meyer, J.P. - Allen, N.J. (1991): A Three-Component Conceptualization of Organizational Commitment. Human Recource Management Review, Vol. 1, pp. 61-89.

Moloney, C.X. (2006): “Winning Your Customer's Loyalty: The Best Tools, Techniques and Practices" AMA Workshop Event(s). Misc. materials distributed related to event(s). San Diego

Morgan, R.M. - Hunt, S.D. (1994): The Commitment-Trust Theory of Relationship Marketing. Journal of Marketing, Vol. 58. July. pp. 20-38.

Neal, W.D. (1999): Satisfaction is Nice, But Value Drivers Loyalty. Marketing Research, Spring, Vol. 11. Issue. 1.

Newall, J. (1977): Industrial Buyer Behaviour: A Model of the Implications of Risk Handling Behaviour for Communication Policies in Industrial Marketing. European Journal of Marketing, Vol. 11. No. 3. pp. 166-211.

Newman, J.W. - Werbel, R.A. (1973): Multivariate Analysis of Brand Loyalty for Major Household Appliances. Journal of Marketing Research, Vol. 10. Nov. pp. 404409. (In: Oliver, 1999)

Nielson, C.C. (1996): An Empirical Examination of Switching Cost Investments in Business-to-Business Marketing Relationships. Journal of Business and Industrial Marketing, Vol. 11. No. 6. pp. 38-60.

Oliver, R.L. (1997): Satisfaction: A Behavioral Perspective on the Consumer, New York: Irwin/McGraw-Hill.

Oliver, R.L. (1999): Whence Consumer Loyalty? Journal of Marketing. Vol. 63. (Special Issue) pp. 33-44.

Parasuraman, A. - Grewal, D. (2000): The Impact of Technology on the Quality-Value-Loyalty Chain: A Research Agenda. Journal of the Academy of Marketing Science, V. 28. No. 1. pp. 168-174.

Pattersson, P.G. - Smith, T. (2003): A Cross Cultural Study of Switching Barriers and Propensity to Stay Whith Service Providers. Journal of Retailing, Vol. 79. pp. 107-120.

Pritzhard, M.P. - Havitz, M.E. - Howard, D.R. (1999): Analyzing the Commitment-Loyalty Lonk in Service Contexts. Journal of the Academy of Marketing Science, Vol. 27. Issue 3. p 333.

Reicheld, F.F. (1996): The Loyalty Effect. Boston, MA: Harvard Business School Press. (In: Oliver, 1999.)

Reicheld, F.F. - Sasser, W.E. (1990): Zero Defections: Quality Comes to Services. Harvard Business Review, Vol. 8. Sept./Okt.
Rekettye, G. (2000): Fogyasztói közérzet-2000. Marketing \& Menedzsment, 6. sz. pp. 7-11.

Rekettye, G. - Hetesi E. (2001): A lakossági fogyasztók lojalitásának mérése és elemzése egy közép kelet-európai energiaszolgáltató szervezetnél. Vezetéstudomány, 9. sz. pp. 17-25.

Reynolds, K.E., - Beatty, S.E. (1999): Customer Benefits and Company Consequences of Customer-Salesperson Relationships in Retailing. Journal of Retailing, Vol. 75. No. 1. pp. 11-32.

Rowley, M.L. - Dawes, J. (2000): Disloyalty: A Closer Look at Non-Loyals. Journal of Consumer Marketing, Vol. 17. No. 6. pp. 538-547.

Singh, J. - Sirdeshmukh, D. (2000): Agency and Trust Mechanisms in Consumer Satisfaction and Loyalty Judgments. Journal of the Academy of Marketing Science, V. 28. No. 1. pp. 150-167.

Stagen, B.P. (1997): An analysis of Central Illinois Public Service Company. Management Quarterly, Summer, Vol. 38. Issue 2. p. 30. p. 7.

Swan, J.A. - Mercer, A.A. (1981): Consumer Satisfaction as a Function of Equity and Disconfirmation, in R. L. Day 0 H. K. Hunt (eds.), Refining Concepts and Measures of Customer Satisfaction and Complaining Behavior, pp. 7-12. Bloomington (IN), Indiana University

Tellis, G.J. (1988): Advertising Exposure, Loyalty and Brand Purchase: A Two - Stage Model of Choice. Journal of Marketing Research, 25. May, pp. 134-144.

Thibaut, J.W. - Kelley, H.H. (1959): The Social Psychology of Groups. New York/London/Sydney

Tuckman, B.W. (1965): Developmental sequence in small groups, Psychological Bulletin, No. 63. pp. 384-399.

Vollmer, I. - Johnson, M. - Herrmann, A. - Huber, F. (2000): The Loyalty of Dissatisfied Customers: Determinants and Impications. XXV. Annual Coloquium on Research in Economic Psychology and SABE 2000 Conference, Baden, Vienna/Austria

Wathne, K.H. Biong, H. - Heide, J.B. (2001): Choice of Supplier in Embedded Markets: Relationship and Marketing Program Effects. Journal of Marketing, Vol. 65. pp. $54-66$.

White, I. - Yanamandram, V. (2004): Why Customers Stay: Reasons and Consequences of Inertia in Financial Services, Managing Service Quality, Vol. 14. No. 2/3. pp. 183-194.

Yanamandram, V. - White, L. (2006): Switching Barriers in Business to Business Services: A Qualitetive Study" International Journal of Service Industry Management, Vol. 17. No. 2. pp. 158-192.

Zeithaml, V.A. (2000): Service Quality, Profitability, and the Economic Worth of Customers: What We Know and What We Need to Learn? Journal of the Academy of Marketing

Science, Winter, Vol. 28. Issue 1. 